\title{
Profitability Determinants of the Ghanaian Banking Sector in Ongoing Wave of Consolidation
}

\author{
Isaac Boadi ${ }^{1}$ \\ ${ }^{1}$ School of Management, Open University, Heerlen, The Netherlands \\ Correspondence: Isaac Boadi, School Box 580 Darkuman, Accra, Ghana. Tel: 233-208-098-029. E-mail: \\ kwameperp@yahoo.co.uk
}

Received: October 1, 2015

Accepted: October 22, 2015

Online Published: November 25, 2015

doi:10.5539/ijbm.v10n12p1

URL: http://dx.doi.org/10.5539/ijbm.v10n12p1

\begin{abstract}
The purpose of this research is to examine the influence of both internal and external factors that determine the profitability of Ghanaian banks. The period under consideration extends from 1997-2014. To determine factors that determine the commercial bank profitability in Ghana, the research employed random effects and pooled ordinary least square models. Internal variables, both financial and non-financial were obtained from the database of Ghana Association of Bankers over the period 1997-2014. The macroeconomic variables were retrieved from Ghana Statistical Service (GSS) and Bank of Ghana (BOG) databases. The results of our study reveal that internal and external variables significantly influence bank profitability, non-interest income is not the sole determinant of profitability as other internal variables, such as capital to assets, GDP growth are statistically significant. However, determinants such as liquidity, deposit ratio, overhead, non-performing loans, number of employees, inflation and real interest rate do not impact significantly on banks' profitability in Ghana. The research could not include more qualitative factors. Future research could include more qualitative factors, for example, management leadership style with the quantitative factors and test the long run effects using a cointegration approach. The main value of this paper is the analysis of new empirical evidence using a current data.
\end{abstract}

Keywords: profitability, Ghanaian banks, inflation, determinants

\section{Introduction}

The efficiency and stability of the financial sector are important to economic growth (Levine, 1997; Rajan \& Zingales, 1998). Researchers have argued that economic growth can never be achieved without the development of the financial sector (Lin \& Nugent, 1995). Ghana's financial sector is regarded relatively well developed. The recent financial crisis has showed that an efficient financial system is critical for economic growth. Bawumia et al. (2008) indicate that the banking sector accounts for $70 \%$ of the financial sector banking. This implies that the sector plays an important role since a failure of this sector could have adverse effect on the entire economy. The industry's profit before tax margin has improved significantly from 17\% to 45.3\% between 2009 to 2013 respectively. In the period under study, the return on assets (ROA) improved significantly from $1.4 \%$ to 4.1\%.Between 2012 and 2013, total assets grew by 13\% from GHS27, 100m to GHS36, 100m. Average Return on equity in the same period stood at $27.5 \%$ from $23.8 \%$. Although the industry profitability was affected during the financial melt down between 2008 and 2011, the impact or the losses were significant. Besides, within the Sub-Saharan Africa banks appear to be very profitable. Flamini et al. (2009) found that for the past 10 years the average returns on assets stood at 2 percent clearly above the other parts of the world.

Recently, determinants of banks profitability have been debated and received a lot of scholarly attention. In 2010 , the then governor of the central bank of Ghana posed a question "what factors have been driving higher profits in the banks in Ghana?" (Daily Graphic, 2010). This question has drafted many researchers and policy makers into several debates in Ghana, all in the pursuit to derive some reasons for the huge performance gab among Ghanaian banks. Factors that determine commercial bank profitability have been supported theoretically but it lacks an empirical support. The present study seeks to examine the influence of both internal and external factors that determine commercial banks profitability in Ghana in the ongoing wave of consolidation. Mullineaux (1978) study concludes that the composition of balance sheet has significant effects on profitability. The relationship can either be positive or negative depending on the structure of the balance sheet items. This makes previous 
research mixed and inconclusive. The inconclusive findings of previous studies indicate that this problem deserves new research. First and foremost, findings from this research would contribute immensely in formulating future policies by bank managers and regulatory authorities which would target in improving the profitability of the commercial banks. In addition, since early 2011 the banking sector has witnessed significant amount of merger and activities with some observers predicting further merger activity and view recent capital requirement increases as being aimed at spurring consolidation (Essien, 2014). Therefore the relevance of this study for the ongoing wave of consolidation banking markets cannot be under estimated. Finally, there is no recent study on the factors that determines commercial banks profitability in Ghana using a current data.

The study employed random effects and pooled ordinary least square models to examine the factors that determine commercial Bank profitability in Ghana using data from 1997 to 2014. The study sample period is seen to be adequate and important to draw robust results about the significant determinants of commercial banks profitability.

The rest of the paper is organized as follows: The next session provides a review of related studies. Section three describes the data and methodology. Section four discusses the results of the empirical analysis and section five provides discussions and recommendation of the study.

\section{Related Studies}

Recent studies have focused more attention on factors that determines commercial bank profitability. The bank profitability determinants are grouped into internal factors (Bank specific) and external factors (country specific). Among the internal factors are financial statements factors and non-financial statement factors such as number of employees and number of branches. Mullineaux (1978) and Hester and Zoellner (1996) studies found that changes in balance sheet items affect bank profitability significantly. Heggested (1977), note that liability items and assets items have an adverse and positive impact on profitability respectively. Emery (1971) also found positive impact on profitability whiles Heggested (1977) Smirlock (1985) and Kwast and Rose (1982), found that size has no effect on profitability. Hester and Zoellner (1966) also found no relationship between size and profitability.

Bourke (1989), the first to capture internal variables in a profitability study, revealed that all internal variables were directly associated to profitability. Molyneux and Thornton (1992) found similar results to support Bourke's study using all European banks in their study sample. Effects of internal determinants on bank profitability have been studied by a lot of researchers using American data and among these notable researchers are Hester and Zoellner (1966), Haslem (1968, 1969), Fraser and Rose (1971), Fraser et al. (1974), Heggested (1977), Mullineaux (1978), Kwast and Rose (1982), Smirlock (1985), except Bourke (1989), Molyneux and Thornton (1992) and Stienherr and Huveneers (1994) which used international data. Fraser and Rose (1971) and Haslem (1968) found that balance sheet items and portfolio selection do not affect profitability. Similarly, Haron (2004) finds that money supply, liquidity, expenditures and the levels of interest rates have positive influence on profitability whereas capital and market share affect profitability negatively. Hassan \& Bashir (2003) note that an increase in capital ratio and loan ratios affect profitability measures positively and negatively respectively. Haron and Azmi (2004) study also conclude that market share capital structure, liquidity and bank sizes have no impact, while deposit, asset structure, total expenditures, consumer price index and money supply affect profitability significantly. Naceur (2003) concludes that the stock market development, capital ratio and loans positively affect profitability whereas bank's size shows a negative impact.

This study will use return on asset (ROA) as one measure of profitability to capture the effects of determinants (internal and external) on commercial bank profitability. Keeton and Matsunga (1985) argue that ROA is a superior indicator of calculating bank profitability since it measures how profitably and efficiently management is using its assets. The following research works have adopted ROA as an adequate indicator of measuring commercial bank profitability: Haron (2004), Hassan and Bashir (2003), Bashir (2001), Demirgüç-Kunt and Huizinga (1998), Naceur (2003), Alkassim (2005), and Alrashdan (2002). Among the internal factors to be adopted in this study and operationalised are: liquidity ratio, capital structure, deposit structure, expenditure structure, efficiency, asset quality and bank size. External determinants of profitability are Gross domestic products (GDP) growth measuring economic growth, interest rate and inflation. These factors that are not under management control (Rasia, 2010). Among the widely discussed external variables to be used in this research are economic growth, inflation and real interest rate. The main objective is to see how the profitability of commercial banks responds to changes in these factors.

First and foremost, liquidity ratio is measured by the liquid assets over total assets. It measures the ability of banks to meet short-term obligation or commitments when they fall due. Banking regulators consider liquidity as 
a major concern for banks since a shortage can trigger bank failure. Various studies used different measures for liquidity including Bashir (2001), Hassan and Bashir (2003), and Alkassim (2005). Indeed, Guru et al. (1999) and Molyneux and Thornton (1992) found that inverse relationship exists between the level of liquidity and profitability. Notwithstanding, Kosmidou et al. (2005) and Bourke (1989), found a direct correlation between liquidity and bank profits. The mixed result requires further empirical work.

Hypothesis 1 : There is a direct association between liquidity and profitability.

The capital ratio as a proxy for capital structure is also utilized as a safety indicator. Alkassim (2005) confirms an inverse effect of capital on profitability of commercial banks. Hassan and Bashir (2003) and Haron (2004) find a strong and direct association between capital and return on assets. Bashir (2001) had earlier years confirmed this position and supported by Athanasoglou et al. (2008), who note that capital is essential in explaining bank profitability. The study therefore expects a direct correlationship between the amount of capital and the bank's profitability.

Hypotheis 2: There is a direct association between the capital structure and profitability.

The customers' deposit over total assets is widely used as a deposit structure. Heggested (1977), Smirlock (1985) and Alkassim (2005) confirmed that demand deposits are positively related to bank profitability but an inverse with time and saving deposit. Demirgüç-Kunt and Huizinga (1998) empirically tested this relationship and concluded that that commercial Banks that depend hugely on deposits as their main sources of funds were less profitable because of the inherent expenditure in attracting such deposit. Thus, the study hypothesizes the following relationship:

Hypothesize 3: There is a direct association between deposit structure and bank profitability.

Overhead as a proxy for expenditure structure variable represents the banks entire overhead over total assets and is a good measure of management efficiency. Bashir (2001) and Hassan and Bashir (2003) confirm relationship between overhead expenses and bank's profitability. Stienherr and Huveneers (1994), Demirgüç-Kunt and Huizinga (1998) and Haron (2004) findings revealed commercial bank's profitability would respond positively to variations in operating costs since these overheads are later on transferred to their customers (both depositors and lenders). Alrashdan (2002) however, contradicts these findings and affirms an inverse association between interest cost and return on assets as a profitability measurement. This study hypothesizes a negative relationship since best managers are judged based on their ability to control operating cost.

Hypothesize 4: There is a negative relationship between expenditure structure and bank profitability

Non-interest income which includes foreign exchange profit, guarantee fees, commission, fees and service charges have been used as a proxy measure of bank efficiency. Bolda and Verma (2006) analysis indicated that contingencies and spread, operating expenses, non-interest income, provision and have significant relationship with net profit. This study hypothesizes a direct association between efficiency and bank profitability.

Hypothesis 5: There is a positive relationship between efficiency and bank profitability.

Provision for bad loans to advances measures the credit quality of the bank. The relationship between the quality of assets and bank profitability has not been underestimated by many researchers. Among the studies are DeYoung and Rice (2004), Athanasoglou et al. (2008), Alexiou and Sofoklis (2009) and Chiorazzo et al. (2008). Kosmidou (2008), confirm that poor asset quality can have adverse impact on bank profitability which clearly supports the risk return hypothesis. Thakor (1987) and Miller and Noulas (1997) also suggest future performance responds largely to the level of loan loss provisions i.e. unpaid loans decreases profitability. Consequently, the study exhibits the following hypothesis:

Hypothesis 6: There is a negative association between assets quality and bank profitability.

The size of a firm can be measured using assets, sales and employees. The study uses employees as a measure of size. Haron (2004) and Hassan and Bashir (2003) find opposite results between size and profitability. Whiles the former finds a direct relationship, the later confirms a negative relationship. The study hypothesizes an inverse relationship between profitability and the number of employees. The negative sign would indicate that the rate of increase in profitability responds to a variation in the number of employees.

Hypothesis 7: There is a negative relationship between number of employees and bank profitability.

Gross domestic products (GDP) which is used as a proxy for economic growth and a good measure of total economic activity within a country. Economic growth is expected to have a direct impact on bank profitability (Athanasoglou et al., 2008; DemirgucKunt \& Huizinga, 1999). Athanasoglou et al. (2008) and Calza et al. (2003) have shown that when economic conditions is improved, it affects the liquidity position of borrowers and 
demand for household which affects the profitability of the bank. In contrast, poor economic conditions have the tendency of worsening quality of loan portfolio thereby reducing bank profitability. Thus, the study hypothesizes a positive relationship.

Hypothesis 8: There is a positive relationship between economic growth and bank profitability.

Another variable which is not under the management control is inflation. This is measured by the percentage increase in consumer price index. Haron and Azmi (2004) and Staikouras and Wood (2003) confirmed that inflation impact positively on profitability. Bourke (1989) and Molyneux and Thornton (1992) empirically tested Revell (1979) findings which suggested that bank profitability responds positively to variations in inflation. Heggested (1977) indicates no relationship between inflation and a bank's profitability. The effect of inflation on bank profitability depends on whether inflation is anticipated or unanticipated (Perry, 1992)

Hypothesis 9: There is a positive relationship between inflation and bank profitability

Studies by Bourke (1989), Claeys and Vander Vennet (2008), DemirgucKunt and Huizinga (1999), GarciaHerrero et al. (2009) and Molyneux and Thornton (1992). Avkiran (2009) notes that, interest rates negatively affect commercial bank profitability. The study formulates two hypotheses.

Hypothesis 10a: There is a positive relationship between interest rates and bank profitability.

Hypothesis 10b: There is a inverse relationship between interest rates and bank profitability.

\section{Data and Methodology}

Internal variables both financial and non-financial were collected from the financial statements of the sampled commercial banks operating in Ghana compiled by Ghana Association of Bankers over the period 1997-2014. The macroeconomic variables are retrieved from Ghana Statistical Service (GSS) and Bank of Ghana (BOG) respectively. Dependable variable, independent variables and expected signs are displayed in Table 1.

Table 1. Dependable variables, Independent variables and expected signs

\begin{tabular}{llc}
\hline Variables & Definition & Hypothesized relationship \\
\hline Dependable Variables & Return on assets & N/A \\
ROA & & \\
Independable Variables & & \\
Internal factors & Liquidity & + \\
LIQ & Capital/Total assets & + \\
CTA & Deposits/Total assets & + \\
DEPTA & Overhead/Total assets & - \\
OVTA & Non-interest income/Total assets & + \\
NOIITA & Non-performing loans/Total Loans & - \\
NPLTA & Number of employees & - \\
NEMP & & + \\
External factors & Gross Domestic Product Growth & + \\
GDPG & Inflation & $-/+$ \\
INFL & Real Interest Rate & \\
IRR & & \\
\hline
\end{tabular}

Note. The data for the calculation of internal factors were obtained from the financial statements of a sample of commercial banks operating in Ghana compiled by Ghana Association of Bankers over the period 1997-2014 The macroeconomic variables are retrieved from Ghana Statistical Service (GSS) and Bank of Ghana (BOG) respectively.

\subsection{Econometric Specification}

To estimate the determinants of bank profitability of Ghanaian banks, the model employed is specified as follows:

$$
\begin{aligned}
& R O A_{i t}= \beta_{0}+\beta_{1} L I Q_{i t}+\beta_{2} C T A_{i t}+\beta_{3} D E P T A_{i t}+\beta_{4} O V T A_{i t}+\beta_{5} N O I I T A_{i t}+\beta_{6} N P L T A_{i t}+\beta_{7} N E M P_{i t}+ \\
& \beta_{8} G D P G_{i t}+\beta_{9} N F L_{i t}+\beta_{10} R I R_{i t}+\varepsilon_{i t}
\end{aligned}
$$

Where ROA is return on assets, LIQ is Liquidity ratio, CTA is capital to total assets ratio, DEPTA is deposits to total assets ratio, OVTA is overhead to total assets ratio, NOIITA is non-interest income to total assets ratio, 
NPLTA is non-performing loans to total assets ratio, NEMP is number of employees, GDPG is the economic growth INFL is inflation and RIR is real interest rate, $\beta_{0}$ is a constant term and $\varepsilon_{\text {it }}$ is the error term. The index $i$ represent banks and $t$ indexes the time period in years. Data for the study were drawn mainly from the annual audited financial reports of banks prepared by Ghana Association of Bankers for the period, 1997-2014. To ensure efficient, reliable, unbiased, consistent and precise prediction of the model to be estimated, unit roots tests, heteroscedasticity, multicollinearity are carried out. It is appropriate to carry out a unit root test in panel datasets to avoid spurious regression estimates which relates to the occurrence of unrelated regressions. Panel stationary test is conducted by the Fisher-type tests (based on Augmented Dickey-Fuller (DF) tests) that are appropriate for unbalanced panel datasets (Baltagi, 2005). The problem of heteroscedasticity occurs when variance of the error terms differ across observations. The problem can be solved by using robust standard errors. The robust standard errors relax OLS assumption that errors are both independent and identically distributed. Multicollinearity exists when two or more independent variables are correlated in a regression model. Although OLS estimators are best, linear, unbiased and efficient, their variances and covariance may be large. The t-ratio of one or more coefficients become statistically insignificant whilst the R-squared tends to be very high (Gujarati, 1995). The afore-mentioned consequences make regression estimates less precise and reliable. Several ways can be used to detect the presence of multicollinearity. This includes auxiliary regressions, correlation matrix, eigenvalues and condition index. But this study will apply the variance inflation factor (VIF). Results of unit roots tests, heteroscedasticity, multicollinearity, Breusch and Pagan Lagrangian Multiplier Test and Hausman specification tests are presented in the appendix. Tables 2 present the results of the summary statistics.

Table 2. Variable definition and summary statistics

\begin{tabular}{llllll}
\hline Variables & Definition & Mean & Standard Deviation & Min & Max \\
\hline ROA & Return on assets & 2.608694 & 5.767586 & -67.7897 & 48.21884 \\
LIQ & Liquidity & 17.46109 & 14.06965 & 0.001 & 152.657 \\
CTA & Capital/Total assets & 15.33563 & 14.49943 & 0.0008 & 188.7808 \\
DEPTA & Deposits/Total assets & 69.11076 & 25.54647 & 0.001 & 384.4936 \\
OVTA & Overhead/Total assets & -6.01134 & 3.050571 & -23.5068 & -0.003 \\
NOIITA & Non-interest income/Total assets & 5.097528 & 4.287268 & 0.0034 & 62.19448 \\
NPLTA & Non-performing loans/Total Loans & -1.40907 & 1.583744 & -14.4331 & 1.453306 \\
NEMP & number of employees & 513.0337 & 519.5996 & 11 & 2875 \\
GDPG & Gross Domestic Product Growth & 6.765928 & 2.924786 & 3.7 & 15.00889 \\
INFL & Inflation & 15.90951 & 7.694838 & 8.58 & 40.5 \\
RIR & Real Interest Rate & 18.01074 & 4.819101 & 12.5 & 27 \\
\hline
\end{tabular}

Source: Author's estimate (2015) using STATA 13.

\section{Empirical Results}

The results of the study are displayed in Table 3. Econometrics theory has highly recommended RE estimation technique for panel datasets that are not balanced since its results are more efficient than FE estimates as confirmed by the Hausman test. This section therefore compares results of both the RE and Pooled OLS estimations. 
Table 3. Fixed effects, random effects and pooled OLS regression results for all sample banks

\begin{tabular}{|c|c|c|c|c|c|c|}
\hline \multirow{2}{*}{$\begin{array}{l}\text { Variable } \\
\text { Dependent variable=ROA }\end{array}$} & \multicolumn{2}{|l|}{ FE Model } & \multicolumn{2}{|l|}{ RE Model } & \multicolumn{2}{|c|}{ Pooled OLS } \\
\hline & Coeff & P.Value & Coeff & P.Value & Coeff & P.Value \\
\hline \multicolumn{7}{|l|}{ Internal Factors } \\
\hline LIQ & 0.004317 & 0.884 & 0.016049 & 0.576 & 0.019494 & 0.492 \\
\hline DEPTA & -0.02121 & 0.121 & -0.01809 & 0.176 & -0.01638 & 0.212 \\
\hline OVTA & -0.17374 & 0.119 & -0.06882 & 0.512 & -0.06049 & 0.564 \\
\hline NOIITA & 0.369336 & $0.004^{* * *}$ & 0.256492 & $0.042 * *$ & 0.225998 & $0.071 *$ \\
\hline CTA & 0.065008 & $0.003^{* * *}$ & 0.088737 & $0.000 * * *$ & 0.094263 & $0.000 * * *$ \\
\hline NPLTL & -0.08482 & 0.657 & 0.121667 & 0.506 & 0.156942 & 0.381 \\
\hline NEMP & 0.000175 & 0.883 & -0.00016 & 0.827 & -0.00823 & 0.886 \\
\hline \multicolumn{7}{|l|}{ External Factors } \\
\hline GDPG & 0.195235 & 0.145 & 0.193133 & $0.094 *$ & 0.18126 & $0.085^{*}$ \\
\hline INFL & -0.01834 & 0.729 & -0.00695 & 0.999 & 0.006727 & 0.904 \\
\hline RIR & 0.12337 & 0.274 & 0.11996 & 0.292 & 0.105198 & 0.365 \\
\hline CONS & 1.932238 & 0.456 & 2.298459 & 0.384 & 2.260029 & 0.395 \\
\hline No. of Observations & & & & & 323 & \\
\hline Group Banks & 29 & & 29 & & 29 & \\
\hline R-squared & 0.2816 & & & & 0.3564 & \\
\hline Adj R-squared & & & & & 0.3231 & \\
\hline F-Statistics & Prob $>$ F & & & & & \\
\hline$F(16,281)=10.24$ & 0.000 & & & & & \\
\hline Wald Statistics & & & Prob $>$ chi2 & & & \\
\hline Wald chi2 $(16)=162.76$ & & & 0.000 & & & \\
\hline F-Statistics & & & & & Prob $>$ F & \\
\hline$F(16, \quad 309)=10.69$ & & & & & 0.000 & \\
\hline
\end{tabular}

Source: Author's estimate (2015) using STATA 13.

The highly significant Wald statistic and F statistic in the RE and pooled OLS models, respectively, confirm that the model employed and all the selected variables are correctly specified.

Commercial bank profitability responds positively to changes in Non-interest income to total assets ratio and is significant at 5 percent level per RE estimation. The result is consistent with Bolda and Verma (2006) and Canals (1993) analysis which indicated that financial variables have significant relationship with profitability. Although the positive relation still exists as regards the pooled OLS method of estimation, it is significant at 10 percent. The implication is that banks that reap higher non-interest income sources such as fee-based services enjoy higher profits. This contradicts earlier findings by Stiroh and Rumble (2006).

This study found a significant relationship between capital structure and profitability and this correspond and consistent with the findings reported by Bourke (1989), Molyneux and Thornton (1992), Stienherr and Huveneers (1994), Isik and Hassan (2003), Staikouras and Wood (2003), Goddard et al. (2004) Pasiouras \& Kosmidou (2007) and Kosmidou (2008). The study also found that capital to assets ratio is significant and directly associated to bank profitability in Ghana, at 1 percent level of significance in both RE and pooled OLS estimations. This implies that well capitalized banks are likely to make higher profits, reinvest (if the profits are not paid out as dividends) and enjoy higher profits through the multiplier effect. A well capitalized bank provides additional strength to operate during financial crises and increased safety for depositors during unstable macroeconomic conditions.

The only external factor that was found to determine bank profitability was GDP growth. This measures the level of economic activities and it was at 10 percent level of significance. The implication is that, in periods where the country enjoys higher economic growth, banks enjoy higher profits. The results do not support the earlier work by Ben Naceur and Omran (2008) and supports the result of Demirguc-Kunt et al. (1998), Bikker et al. (2002), and Athanasoglou et al. (2005).

\section{Discussions and Recommendations}

The present study employed random effects (RE) models and Pooled OLS to explore the factors that determine 
commercial banks profitability in Ghana. The model has been supported by Hausman specification test. This paper empirically investigates profitability determinants of the Ghanaian banking sector in the ongoing wave of consolidation spanning from 1997 to 2014 using panel data set of 323 observations.

Our study concludes that internal and external variables enhance commercial banks profitability. Findings from this provide empirical evidence to suggest that Non-interest income to total assets ratio as a proxy for management efficiency is positively associated with profitability of Ghanaian banks.

The study also revealed that better capitalized banks tend to be more profitable and often avoid bankruptcy. Therefore banks should be capitalization to prevent external shocks, retained earnings and be discouraged in giving out exorbitant bonuses.

Besides, that only exogenous variable (not under management control) that confirmed a positive relationship with profitability in Ghana by our study was economic growth. A strong and efficient banking system is function of a healthy economy, therefore a positive relationship of the exogenous variable with commercial banks profitability is in line with theory.

Determinants such as liquidity, deposit ratio, overhead, non-performing loans, inflation and real interest rate are insignificant in explaining banks' profitability in Ghana. This has been left unexplored and it deserves a new research.

The relevance of the study are as follows: profitable banks are able to offer more and new products and services, unusually high returns should prompt policymakers to introduce measures to help curb this, entry barriers should be reconsidered by regulators, banks should be well capitalized if they are to avoid going bankruptcy and robustness and stability of the banking sector should be a concerned to the supervision and regulatory departments of the bank of Ghana.

Given the key role that the financial sector plays in the expansion of the private productive, future research work should measure and access the impact of monetary policy of the Central Bank.

\section{References}

Alexiou, C., \& Sofoklis, V. (2009). Determinants of bank profitability: Evidence from the Greek banking sector. Economic Annals, 182, 93-118. http://dx.doi.org/10.2298/EKA0982093A

Alkassim, F. A. (2005). The Profitability of Islamic and Conventional Banking in the GCC Countries: A Comparative Study. University of Wales Bangor, United Kingdom.

Alrashdan, A. (2002). Profitability Determinants of Jordanian Commercial Banks. Al al-Bayt University, Mafraq, Jordan.

Baltagi, B. H. (1998). Within two way equivalent to two within one way problem. Econometric Theory, 13, 759.

Bashir, \& Abdel-Hameed, M. (2001). Assessing the performance of Islamic Banks: Some evidence from the Middle East 21st annual meeting of Middle East Economic Association, in conjunction with Allied Social Sciences Association in New Orleans, Louisiana, U.S.A., January 7-9, 2001.

Bawumia, M., Owusu-Danso, T., \& McIntyre, A. (2008). IMF Survey Magazine: Countries \& Regions, Ghana's reforms transform Its financial sector. Retrieved from http://www.imf.org/external/pubs/ft/survey/so/2008/car052208a.htm

Bekoe, K. A. A. (2010). What factors have been driving higher profits in the banks in Ghana? Daily Graphic Newspaper, 34.

Ben Naceur, S., \& Omran, M. (2008). The Effects of Bank Regulations, Competition and Financial Reforms on Mena Banks' Profitability. Working Paper. Economic Research Forum.

Bikker, J., \& Hu, H. (2002). Cyclical patterns in profits, provisioning and lending of banks and procyclicality of the New Basel Capital Requirements. BNL Quarterly Review, 221, 143-175.

BoG. (2014). Supervision and regulation. Retrieved from http://www.bog.gov.gh/index.php

Boldla, B., \& Verma, R. (2006). Determinants of profitability of banks in India: A multivariate analysis. Journal of Services Research, 6(2), 75-89.

Bourke, P. (1989). Concentration and Other Determinants of Bank Profitability in Europe, North America and Australia. Journal of Banking and Finance, 13, 65-67. http://dx.doi.org/10.1016/0378-4266(89)90020-4

Calza, A., Gartner, C., \& Sousa, J. (2003). Modeling the demand for loans to the private sector in the euro area. Applied Economics, 35, 107-117. http://dx.doi.org/10.1080/00036840210161837 
Chiorazzo, V., Milani, C., \& Salvini, F. (2008). Income diversification and bank performance: Evidence from Italian banks. Journal of Financial Services Research, 33, 181-203. http://dx.doi.org/10.1007/s10693-008-0029-4

Claeys, S., \& Vander, V. R. (2008). Determinants of bank interest margins in Central and Eastern Europe: A comparison with the West. Economic Systems, 32, 197-216. http://dx.doi.org/10.1016/j.ecosys.2007.04.001

Demirgüç-Kunt, A., \& Huizinga, H. (1998). Determinants of commercial bank interest margins and profitability: Some international evidence. The World Bank Economic Review, Oxford University Journal, 13(2), 379-408.

DeYoung, R., \& Rice, T. (2004). Non interest income and financial performance at US commercial banks. The Financial Review, 39, 101-127. http://dx.doi.org/10.1111/j.0732-8516.2004.00069.x

Eichengreen, B., \& Gibson, H. D. (2001). Greek banking at the dawn of the new millennium. CEPR Discussion Paper.

Emery, J. (1971). Risk, Returns, and the Morphology of Commercial Banking. Journal of Financial and Quantitative Analysis, 6(2), 763-776. http://dx.doi.org/10.2307/2329711

Essien, A. (2014). Banking in Africa: Lessons from a top banker. Retrieved from www.http://citifmonline.com/2014/12/18/ecobank-boss-calls-mergers-acquisitions-banksGhana/\#sthash.Uaj eaK56.dpuf

Flamini, V., Mcdonald, C., \& Schumacher, L. (2009). The determinants of commercial bank profitability in Sub-Saharan Africa. IMF Working Paper.

Fraser, D. R., \& Rose, P. S. (1971). Bank Entry and Bank Performance. Journal of Finance, 21(1), 65-78.

Fraser, D. R., Philips, W., \& Rose, P. S. (1974). A Canonical Analysis of Bank Performance. Journal of Financial and Quantitative Analysis, 9, 287-295. http://dx.doi.org/10.2307/2330107

Garci'a-Herrero, A., Gavila', S., \& Santaba' Rbara, D. (2009). What explains the low profitability of Chinese banks? Journal of Banking and Finance, 33, 2080-2092. http://dx.doi.org/10.1016/j.jbankfin.2009.05.005

Goddard, J., Molyneux, P., \& Wilson, J. (2004). Dynamic of growth and profitability in banking. Journal of Money, Credit and Banking, 36(6), 1069-1090. http://dx.doi.org/10.1353/mcb.2005.0015

Gujarati, D. N. (1995). Basic Econometrics (3rd ed.). New York: McGraw-Hill.

Guru B. K., Staunton, J., \& Balashanmugam, B. (1999). Determinants of Commercial Bank Profitability in Malaysia. Paper presented at the 12th Annual Australian Finance and Banking Conference, Sydney, Australia, 16-17 December.

Haron, S. (2004). Determinants of Islamic Bank Profitability. Global Journal of Finance and Economics, 1(1).

Haron, S., \& Azmi, W. N. W. (2004). Profitability Determinants of Islamic Banks: A Cointegration Approach. Islamic Banking Conference. Union Arab Bank, Beirut, Lebanon.

Haslem, J. (1968). A statistical analysis of the relative profitability of commercial banks. Journal of Finance, 23, 167-176. http://dx.doi.org/10.1111/j.1540-6261.1968.tb03004.x

Haslem, J. (1969). A statistical estimation of commercial bank profitability. Journal of Business, 42, 22-35. http://dx.doi.org/10.1086/295162

Hassan, K., \& Bashir, M. (2003). Determinants of Islamic Banking Profitability. International Seminar on Islamic Wealth Creation, University of Durham, U. K.

Heggested, A. A. (1977). Market Structure, Risk, and Profitability in Commercial Banking. Journal of Finance, 32, 1207-1216. http://dx.doi.org/10.1111/j.1540-6261.1977.tb03321.x

Hester, D., \& Zoellner, J. (1966). The Relation between Bank Portfolios and Earnings: An Econometric Analysis. Review of Economics and Statistics, 48, 372-386. http://dx.doi.org/10.2307/1924615

Isik, I., \& Hassan, M. K. (2003). Efficiency, ownership and market structure, corporate control and governance in the Turkish Banking Industry. Journal of Business Finance and Accounting, 30(9/10), 1363-1421. http://dx.doi.org/10.1111/j.0306-686X.2003.05533

Keeton, W. R., \& Matsunaga, L. (1985). Profits of commercial banks in tenth district states. Economic Review of Federal Reserve Bank of Kansas City, 3-22.

Kosmidou, K. (2008). The determinants of Banks' Profits in Greece during the period of EU financial integration, 
Emerald Group Publishing Limited. Managerial Finance, 34(3), 146-159. http://dx.doi.org/10.1108/03074350810848036

Kosmidou, K., Pasiouras, F., \& Tanna, S. (2005). Determinants of Profitability of Domestic UK Commercial Banks: Panel Evidence from the Period 1995-2002. Retrieved from http://repec.org/mmfc05/paper45.pdf

Kosmidou, K., Pasiouras, F., \& Tsaklanganos, A. (2007). Domestic and multinational determinants of foreign bank profits: The Case of Greek Banks operating abroad. Journal of Multinational Financial Management, 17(1), 1-15. http://dx.doi.org /10.1016/j.mulfi n.2006.02.002

Kwast, M. L., \& John, T. R. (1982). Pricing, Operating Efficiency, and Profitability among Large Commercial Banks. Journal of Banking and Finance, 6(2), 233-254. http://dx.doi.org/10.1016/0378-4266(82)90035-8

Levine, R. (1997). Financial development and economic growth: View and agenda. Journal of Economic Literature, 35, 688-726. http://dx.doi.org/10.1006/jfin.1998.0255

Levine, R. (1999). Law, finance and economic growth. Journal of Financial Intermediation, 15, 125-138.

Lin, J. Y., \& Nugent, J. (1995). Institutions and economic development. Handbook of Development Economics, 3, 20.

McKinnon, R. I. (1997). Financial development and economic growth: An Empirical Assessment. The World Bank Economic Review, 7, 65-83.

Miller, S. M., \& Noulas, A. (1997). Portfolio mix and large bank profitability in the USA. Applied Economics, 29, 505-512. http://dx.doi.org/10.1080/000368497326994

Molyneux, P., \& Thornton, J. (1992). Determinants of European Bank Profitability: A Note. Journal of Banking and Finance, 16(6), 1173-1178. http://dx.doi.org /10.1016/0378-4266(92)90065-8

Mullineaux, D. J. (1978). Economies of Scale and Organizational Efficiency in Banking: A Profit-Function Approach. Journal of Finance, 33, 259-280.

Naceur, S. (2003). The Determinants of the Tunisian Banking Industry Profitability: Panel Evidence. Frontiers in Finance and Economics, 5(1), 106-130.

Perry, P. (1992). Do banks gain or lose from inflation. Journal of Retail Banking, 14(2), 25-40.

Rajan, R., \& Zingales, L. (1998). Financial dependence and growth. The American Economic Review, 88, $559-586$.

Rasiah, D. (2010). Review of literature and theories on determinants of commercial bank profitability. Journal of Performance Management, 23-49.

Revell, J. (1979). Inflation and Financial Institutions. Financial Times, London.

Smirlock, M. (1985). Evidence on the Non-Business.

Staikouras, C., \& Wood, G. (2003). The determinants of bank profitability in Europe. Paper presented at the European Applied Business Research Conference, Venice.

Steinherr, A., \& Ch, H. (1994). On the Performance of Differently Regulated Financial Institutions: Some Empirical Evidence. Journal of Banking and Finance, 18, 271-306. http://dx.doi.org/10.1016/0378-4266(94)00036-0

Stiroh, K. J., \& Rumble, A. (2006). The dark side of diversification: The Case of US Financial Holding Companies. Journal of Banking and Finance, 30(8), 2131-2161. http://dx.doi.org/10.1016/j.jbankfi n.2005.04.030

Thakor, A. (1987). Discussion. Journal of Finance, 42, 661-663. http://dx.doi.org/10.1111/j.1540-6261.1987.tb04575.x

Vernon, J. (1971). Separation of Ownership and Control and Profit Rates, the Evidence from Banking: Comment. Journal of Financial and Quantitative Analysis, 6(1), 615-622. http://dx.doi.org/10.2307/2330130 


\section{Appendix}

Appendix A. Fisher unit root test of variables based on ADF

\begin{tabular}{|c|c|c|c|c|c|c|c|c|}
\hline Variables & $\begin{array}{l}\text { Inverse C } \\
\text { Statistic }\end{array}$ & $\begin{array}{l}\text { i sq. } \\
\text { prob }\end{array}$ & $\begin{array}{l}\text { Inverse I } \\
\text { statistic }\end{array}$ & $\begin{array}{c}\text { ormal } \\
\text { prob }\end{array}$ & $\begin{array}{l}\text { Inverse L } \\
\text { statistic }\end{array}$ & $\begin{array}{l}\text { git } \\
\text { prob }\end{array}$ & $\begin{array}{l}\text { Modified } \\
\text { statistic }\end{array}$ & $\begin{array}{l}\text { v. Chi sq } \\
\text { prob }\end{array}$ \\
\hline ROA & 325.4406 & 0.000 & -9.1131 & 0.000 & -16.4402 & 0.000 & 26.1194 & 0.000 \\
\hline LIQ & 117.7524 & 0.000 & -1.9877 & 0.000 & -3.8028 & 0.0001 & 6.1346 & 0.000 \\
\hline DEPTA & 96.2841 & 0.0004 & -3.3179 & 0.0005 & -3.3269 & 0.0006 & 4.0688 & 0.000 \\
\hline OVTA & 180.8325 & 0.000 & -6.9149 & 0.000 & -9.1863 & 0.000 & 12.2045 & 0.000 \\
\hline NOIITA & 210.8886 & 0.000 & -8.1402 & 0.000 & -10.8621 & 0.000 & 15.0966 & 0.000 \\
\hline CTA & 105.0584 & 0.000 & -3.9293 & 0.000 & -4.2173 & 0.000 & 4.9131 & 0.000 \\
\hline NPLTA & 159.5332 & 0.000 & -6.1006 & 0.000 & -7.214 & 0.000 & 10.1549 & 0.000 \\
\hline NEMP & 113.7883 & 0.000 & -4.8829 & 0.000 & -5.4827 & 0.000 & 6.7145 & 0.000 \\
\hline GDPG & 82.6942 & 0.0072 & -3.4639 & 0.0003 & -3.1949 & 0.0009 & 2.7611 & 0.0029 \\
\hline INFL & 204.418 & 0.000 & -6.605 & 0.000 & -9.3628 & 0.000 & 14.474 & 0.000 \\
\hline RIR & 62.2917 & 0.0449 & -3.1094 & 0.0009 & -2.8369 & 0.0027 & 1.6985 & 0.0447 \\
\hline
\end{tabular}

Appendix B. Variance Inflation Factor (VIF) for the explanatory variables

\begin{tabular}{lll}
\hline Variable & VIF & $\mathbf{1 / V I F}$ \\
\hline RIR & 4.5 & 0.2223 \\
NOIITA & 4.14 & 0.241659 \\
INFL & 2.63 & 0.380009 \\
GDPG & 2.3 & 0.435595 \\
LIQ & 2.29 & 0.436454 \\
DEPTA & 1.62 & 0.618367 \\
CTA & 1.49 & 0.669373 \\
OVTA & 1.48 & 0.677827 \\
NEMP & 1.28 & 0.781735 \\
NPLTA & 1.16 & 0.862701 \\
Mean VIF & $\mathbf{2 . 9 3}$ & \\
\hline
\end{tabular}

Source: Author's estimate (2015) using STATA 13.

The mean VIF was 2.93, which is much lower than the threshold of 10. The VIF for individual variables was also below 10 . This indicates that the explanatory variables included in the model were not substantially correlated with each other, indicating an absence of multcollinearity between the variables.

Appendix C. Hausman specification tests between FE and RE estimates

\begin{tabular}{lllll}
\hline Variable & $\begin{array}{l}\text { Coefficients } \\
\text { Fixed(FE) }\end{array}$ & Random(RE) & Difference(FE-RE) & sqrt(diag(v_FE-v_RE)) \\
\hline LIQ & 0.004317 & 0.016049 & -0.011732 & 0.007675 \\
DEPTA & -0.02121 & -0.01809 & -0.0031201 & 0.0027425 \\
OVTA & -0.17374 & -0.06882 & -0.1049235 & 0.0367821 \\
NOIITA & 0.369336 & 0.256492 & 0.1128444 & 0.0129501 \\
CTA & 0.065008 & 0.088737 & -0.0237286 &. \\
NPLTA & -0.08482 & 0.121667 & -0.2064894 & 0.0537529 \\
NEMP & 0.000175 & -0.00016 & 0.0003302 & 0.0009571 \\
GDPG & 0.195235 & 0.193133 & 0.0021024 & $\cdot$ \\
INFL & -0.01834 & -0.00695 & -0.0182754 & $\cdot$ \\
RIR & 0.12337 & 0.11996 & 0.00341 & $\cdot$ \\
FE $=$ consistent under Ho and Ha; obtained from xtreg & $\cdot$ \\
RE= inconsistent under Ha, efficient under Ho; obtained from xtreg \\
Test: Ho: difference in coefficients not systematic \\
chi2 $(16)=\left(\right.$ FE-RE)'[(V_FE-V_RE) $\left.{ }^{\wedge}(-1)\right]$ (FE-RE) \\
$=15.10$ \\
$\begin{array}{l}\text { Prob }>\text { chi2 }=0.5170 \\
\text { (V_FE-V_RE is not positive definite) }\end{array}$ \\
\hline
\end{tabular}

Source: Author's estimate (2015) using STATA 13. 
Thus, the Hausman specification test is carried out to inform whether RE estimation gives more consistent results, given the data used for this study. When Prob $>\operatorname{chi} 2=\alpha$, the null hypothesis is rejected. This reinforces the consistency of the RE in estimating the chosen model.

Appendix D. Breusch and pagan lagrangian multiplier test for random effects

\begin{tabular}{lll}
\hline \multicolumn{2}{l}{ Estimated results: } & \\
\hline & Variable & sd $=\mathbf{s q r t}($ Var) \\
ROA & 33.26504 & 5.767586 \\
$\mathrm{e}$ & 19.37337 & 4.401519 \\
$\mathrm{u}$ & 1.454848 & 1.206171 \\
Test: $\quad \operatorname{Var}(\mathrm{u})=0$ & \\
chibar2 $(01)=0.09$ & \\
Prob $>$ chibar2 $=$ & 0.3810 & \\
\hline
\end{tabular}

Source: Author's estimate (2015) using STATA 13.

This test compares RE estimates and Pooled Ordinary Least Squares (Pooled OLS) estimates for appropriateness. The test tests the hypothesis that Vat $(\mathrm{u})=0$, under the null hypothesis that Pooled OLS estimation has less variation in its residuals than RE estimation. The test failed to reject the null hypothesis that residuals from Pooled OLS have lower variance, although both RE estimates and Pooled OLS estimates are consistent and efficient.

\section{Copyrights}

Copyright for this article is retained by the author(s), with first publication rights granted to the journal.

This is an open-access article distributed under the terms and conditions of the Creative Commons Attribution license (http://creativecommons.org/licenses/by/3.0/). 